\title{
Tobacco Use and the Risk of Suffering from COVID-19
}

\author{
Dianita Sugiyo $^{1,2 *}$, Ralalicia Limato ${ }^{3,4}$, Saskia Dyah Handari, \\ ${ }^{1}$ Department of Nursing, School of Nursing, Faculty of Medicine and Health Sciences, Universitas Muhammadiyah Yogyakarta, \\ Indonesia; ' 2 Muhammadiyah Steps, Universitas Muhammadiyah Yogyakarta, Indonesia; ${ }^{3}$ Eijkman-Oxford Clinical Research \\ Unit, Jakarta, Indonesia; ${ }^{4}$ Centre for Tropical Medicine and Global Health, Nuffield Department of Medicine, University of \\ Oxford, Oxford, UK; ${ }^{5}$ Department of Cardiology, Medical School, Ciputra University, Surabaya, Indonesia; ${ }^{6}$ Department of \\ Cardiology, Siloam Hospital, Surabaya, Indonesia
}

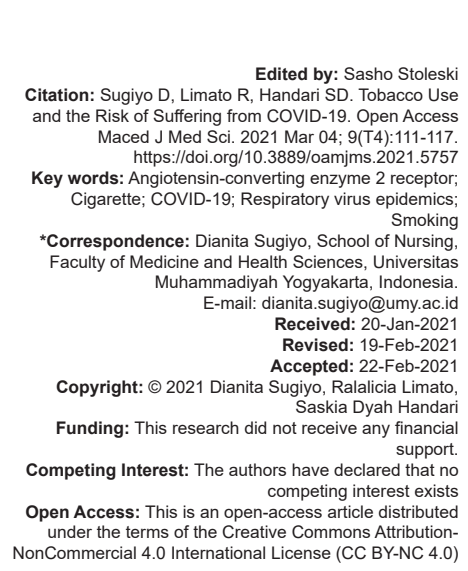

\section{Introduction}

At present, global attention has been directed toward the disease of coronavirus (COVID-19), a respiratory infection lead by coronavirus 2 (severe acute respiratory syndrome coronavirus 2 [SARSCoV-2]) [1] and resulting a respiratory syndrome in severe and acute condition. This illness case was detected first at the end of 2019, specifically December, in district of Wuhan, China; after which the virus spread rapidly over 27 countries [2]. By identifying the global impact, on January 30, 2020, the World Health Organization (WHO) stated that the outbreak of the disease was resulting from coronavirus was a global health emergency [3], [4]. It is reported that the disease caused the high mortality rate. This respiratory infection caused death above 2858 cases, and infected patients more than 83,652 cases globally. This COVID-19 led to the worst mortality rate in Wuhan [3].

The respiratory infections, such as mildto-severe cold, were predominantly transferred by coronavirus as pathogens among humans and animals. These pathogens have been known to cause global respiratory diseases, labeled as "SARS" (SARS-CoV) and specifically in the Middle East as Middle East respiratory syndrome-CoV [3], [5]. Compared to the two previous widespread respiratory diseases cited above, the early stage atypical symptoms of some COVID-19 patients lead this disease to be proven more deadly [3] than the two preceding it. Given the fact that no COVID-19 treatment, with specific antiviral medication or vaccine has been effectively validated, the most valuable thing would be a therapy to support a delay in the symptoms which, in turn, could protect an individual's vital organs [3].

The respiratory droplets produced when people are sneezing, coughing, and exhaling are possibly transmitted through direct interaction among such people [1]. The high fatalities among smokers in China, as the epicenter of pandemic outbreak, were likely due to the high smoking rates among males in the country; around $50 \%$ of the total population [6]. On the other hand, although all the adverse health impact are enhanced by tobacco use, both smoke 
and smokeless tobacco, the world needs to consider action to de-normalize the use of tobacco and highlight the issue of users' and companies' corporate social responsibility [7], [8], [9], [10]. Tobacco use has been widely acknowledged as being related to a range of negative health issues such as: (i) Cardiovascular defects, (ii) respiratory diseases, (iii) cancer, and (iv) reproductive health, as well as other adverse impacts on health. However, the policy of public health for a smoke-free worldwide covers $<20 \%$ of the world's population [10].

The association between smoking activity and either transmission or fatality among confirmed COVID-19 patients has been given little attention [6]. The use of cigarettes and other nicotine delivery modes is open to debate: Whether or not tobacco use contributes to the high number of smokers who have been identified as COVID-19 cases. This review explores the matching evidence-based publications to provide arguments in an effort to respond to this important contemporary issue.

\section{Methods}

\section{Study Design and Data Collection}

Considering the limited amount of literature on COVID-19, proposing a systematic review was as irrelevant among the heterogeneous types of studies [11] as a theoretical qualitative meta-analysis [12]. Therefore, a narrative literature review is employed to obtain an argument to answers the polemic [13].

The analysis focused on compiling the relevant literature published in 2019-2020, from the beginning of the pandemic until April 23 and 24, 2020, when the search took place. The primary concern of the study is the relationship between tobacco use, either conventional cigarettes or smokeless ones (e-cigarettes), and the COVID-19 incident. A keyword search on EBSCOhost and ProQuest databases was performed to identify the articles, followed by a further search manually for other relevant publications. The search terms included "tobacco use," "smokers," "e-cigarette," in combination with "COVID," and "SARSCoV-2." Meanwhile, a manual search of various relevant journals, such as Tobacco Induced Diseases and the European Respiratory Journal, was included as the other reference list of original articles found with the equal search terms. The data collection identified 18 articles, consisting of seven journal articles and 11 academic-related reviews.

An evaluation of the methodological research context was excluded from the study as a systematic review of the papers was deemed inappropriate, due to the very limited number of publications focused on the target issue.

\section{Ethical Consideration}

There is no ethical clearance needed for the study as it used secondary data from several data bases.

\section{Results}

The review classifies two major domains describing the relationship between COVID-19 and cigarette or tobacco use among current and former smokers.

The first group of studies focused on chemical substances in cigarette or Electronic Nicotine Delivery Systems (ENDS). There are five studies [14], [15], [16], [17], [18], [19] exploring the effect of smoking in the human body that decreases the immune system's effectiveness and therefore makes it vulnerable to hosting yet more infections. The following references are shown in Table 1:

Evidence from this group provides perspectives on: (a) The COVID-19 fatalities who were smokers, and (b) the number of patients who recovered, and the severity of organ injuries experienced by the patients, correlated with their COVID-19 prognosis.

The second group of studies employed the role of angiotensin-converting enzyme 2 (ACE2), which has a significant correlation with the lungs' function. The risk of coronavirus infection among smokers is higher as the upregulation of ACE2 is the predisposing factor [20]. Seven studies emphasized how (ACE2) (Table 2), is correlated with the COVID-19 infections and how that led to more severe conditions in smokers; ultimately with fatal conclusions for many [1], [4], [6], [15], [20], [21], [22].

\section{Discussion}

Smokers are more susceptible to respiratory viruses, as the receptor of ACE2 could be "up-regulated" by smoking. ACE2 is known as the receptor or main binding sites of various respiratory infections [1], such as SARS-CoV, and the human respiratory coronavirus NL6386. The classification of smoking also includes the use of electronic devices and the heated model (IQOS device) [6]. 
Table 1: The effects of cigarette chemical substances to the human immune system

\begin{tabular}{|c|c|c|c|c|}
\hline S. No. & Author/Year & Title & Purposes & $\begin{array}{l}\text { Research design, population, and } \\
\text { instrument }\end{array}$ \\
\hline 1 & Chen et al.(2020) & $\begin{array}{l}\text { Clinical characteristics of } \\
113 \text { deceased patients } \\
\text { with coronavirus disease } \\
\text { 2019: retrospective study }\end{array}$ & $\begin{array}{l}\text { To delineate the } \\
\text { clinical characteristics } \\
\text { of patients with } \\
\text { coronavirus disease } \\
2019 \text { who died }\end{array}$ & $\begin{array}{l}\text { Research design: Retrospective } \\
\text { case series } \\
\text { Sample: Among a cohort of } \\
799 \text { patients, } 113 \text { who died } \\
\text { and } 161 \text { who recovered with } \\
\text { a diagnosis of covid-19 were } \\
\text { analyzed } \\
\text { Instrument: Clinical characteristics } \\
\text { and laboratory findings which } \\
\text { obtained from electronic medical } \\
\text { records with data collection forms }\end{array}$ \\
\hline
\end{tabular}

Result

The median age of deceased patients (68 years) was significantly older than recovered patients (51 years). Male sex was more predominant in deceased patients $(83 ; 73 \%)$ than in recovered patients $(88 ; 55 \%)$. Chronic hypertension and other cardiovascular comorbidities were more frequent among deceased patients $(54(48 \%)$ and $16(14 \%))$ than recovered patients $(39(24 \%)$ and $7(4 \%))$. Dyspnea, chest tightness, and

disorder of consciousness were more common in deceased patients $(70[62 \%], 55[49 \%]$, and $25[22 \%])$ than in recovered patients $(50[31 \%], 48[30 \%]$, and $1[1 \%])$. The median time from disease onset to death in deceased patients was 16 (interquartile range 12.0-20.0) days. Leukocytosis was present in $56(50 \%)$ patients who died and $6(4 \%)$ who recovered, and lymphopenia was present in $103(91 \%)$ and $76(47 \%)$ respectively. Concentrations of alanine aminotransferase, aspartate aminotransferase, creatinine, creatine kinase, lactate dehydrogenase, cardiac troponin I, N-terminal pro-brain natriuretic peptide, and D-dimer were markedly higher in deceased patients than in recovered patients. Common complications observed more frequently in deceased patients included acute respiratory distress syndrome $(113 ; 100 \%)$, type I respiratory failure $(18 / 35 ; 51 \%)$, sepsis $(113 ; 100 \%)$, acute cardiac injury $(72 / 94 ; 77 \%)$, heart failure $(41 / 83 ; 49 \%)$, alkalosis $(14 / 35 ; 40 \%)$, hyperkalemia $(42 ; 37 \%)$, acute kidney injury $(28 ; 25 \%)$, and hypoxic encephalopathy $(23 ; 20 \%)$. Patients with cardiovascular comorbidity were more likely to develop cardiac complications. Regardless of history of cardiovascula disease, acute cardiac injury and heart failure were more common in deceased patients

2 World Health Tobacco and waterpipe Organization(2020) use increase the risk of suffering from COVID-19

3 Sorour(2020)

$4 \quad$ Vardavas and

Nikitara(2020)

Angiotensin-converting
enzyme 2 in the highlight of COVID-19, A proposed pathology and potential correlations

COVID-19 and smoking: A systematic review of th evidence

COVID-19 disease Emergency Operational Instructions for Mental Health Departments

5 Starace and Ferrara(2020)
Recommendations for national authorities, under the WHO Framework Convention on Tobacco Control to protect the public from the devastating health consequences of tobacco use Provide a summary of Clinical trials that concluded the protective roles of Angiotensin-converting enzyme 2-2 in the lungs and brain

Examine the limited data of previous studies with regard to the clinical characteristics of the patients as well as to their prognostic factors

A literature review with resources on findings which related to waterpipe use, tobacco consumption, e-cigarette use and the COVID-19 pandemic

Research design: Literature review

Sample: Clinical trials that concluded the protective roles of Angiotensin-converting enzyme $2-2$ in the lungs and brain. Instrument: -

Research design: a systematic review of studies on COVID-19 Sample: Five studies on COVID-19 which included information on patients smoking status to evaluate the association between smoking and COVID-19 outcomes including the severity of the disease, the need for mechanical ventilation, the need for intensive care unit hospitalization and death. The literatures came from two databases (PubMed, ScienceDirect) Instrument: -

Operational instructions Research design: Literature recommendations review which intended to Sample: Six studies related to protect mental health Covid-19 professionals, users and their families, in the current pandemic for which most of Mental Health Departments worldwide are not prepared to Instrument: -
There is association between waterpipe uses and infectious agents transmitted risk which is increased

Males or smokers have experienced increasing in severity of the disease. The regulation of Angiotensin-converting enzyme 2-2 on viral mediation was related to COVID-19 cases.

Notably, in the largest study that assessed severity, there were higher percentages of current and former smokers among patients that needed ICU support, mechanical ventilation or who had died, and a higher percentage of smokers among the severe cases 12 . However, from their published data we can calculate that the smokers were 1.4 times more likely $(R R=1.4,95 \% \mathrm{Cl}$ : $0.98-2.00)$ to have severe symptoms of COVID-19 and approximately 2.4 times more likely to be admitted to an intensive care unit, need mechanical ventilation or die compared to non-smokers $(R R=2.4$ $95 \% \mathrm{Cl}: 1.43-4.04)$

Operational instructions for Mental Health Departments which include four targets: (1) Outpatient activities, (2) Outpatient services, (3) Day hospitals and day centers, (4) Inpatient units

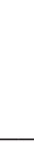


COVID-19 risk is higher in the group of people with a constantly unhealthy behavior and lifestyle [18], [19]. In general, smoking behavior repressed the effective function of the human lung and provoked further inflammation. Particularly for those using the most recent electronic smoking devices, greater repression resulted than for those patients using conventional cigarettes due to the activity of immune and inflammation response genes in the smoker's nasal cells [17]. The capacity of the innate immune system to curb viral replication is diminished by smoking effects, which downregulate CXCL-10, a chemokine that takes a role into macrophages, neutrophils, and natural killer cell recruitment [15].

A further review revealed that waterpipe use [14] and conventional smoking were associated with the adverse progression and detrimental prognosis of COVID-19 [16]. Smokers experience a higher risk of respiratory infection complications than non-smokers, as tobacco destroys ciliated epithelium and reduces lung protection by disrupting the ciliated epithelium's function, which produces mucus and rapid clearance pathogens [15]. Besides, this unhealthy behavior was also associated with the adverse prognosis of acute respiratory distress syndrome [14].

In addition, smoking activities increase hand movements to the face repetitively; a habit which could potentially contribute a route for the viral entries [23]. The use of the waterpipe smoking apparatus was also recognized as increasing the risk of COVID-19 spreading with the nature of communal waterpipe smoking and sharing the apparatus' mouthpiece, especially in social settings [14]. Furthermore, countries with considerable levels of COVID-19 outbreaks, such as China, South Korea, and Italy, were identified as countries with high populations of smokers [23].

\section{COVID-19 receptors}

Human ACE2 has a good binding affinity with SARS-COV-2 spike proteins. Therefore, it is worth considering a suggestion that ACE2 is more efficiently recognized by SARS-CoV-2 correlated to the previous SARS-CoV, which leads to the latest virus transmission ability from person to person [2], [6], Table 2. Host cell entry and viral replication require ACE2 [4], [22]; thus its over-expression heightens the disease severity [2], [6], [15] resulting in the coronavirus using this receptor (epithelial cells) to gain entrance [20], [22] into the epithelial cells. ACE2 was "upregulated" in the smokers' airway epithelium and it was reported that smokers have higher ACE2 gene expression compared to nonsmokers [6] and, as such, have a significant correlation with lung function [20]. These findings indicate that smokers are more vulnerable to the SARS-CoV-2 infection and possibly COVID-19 [6]. Figure 1 illustrates the process of enhanced expression of ACE2 in lung tissue resection of chronic obstructive pulmonary disease (COPD) subjects and smokers with a healthy lung function. It is necessary to remind that ACE2 is absent from the non-smoking people's samples [6].

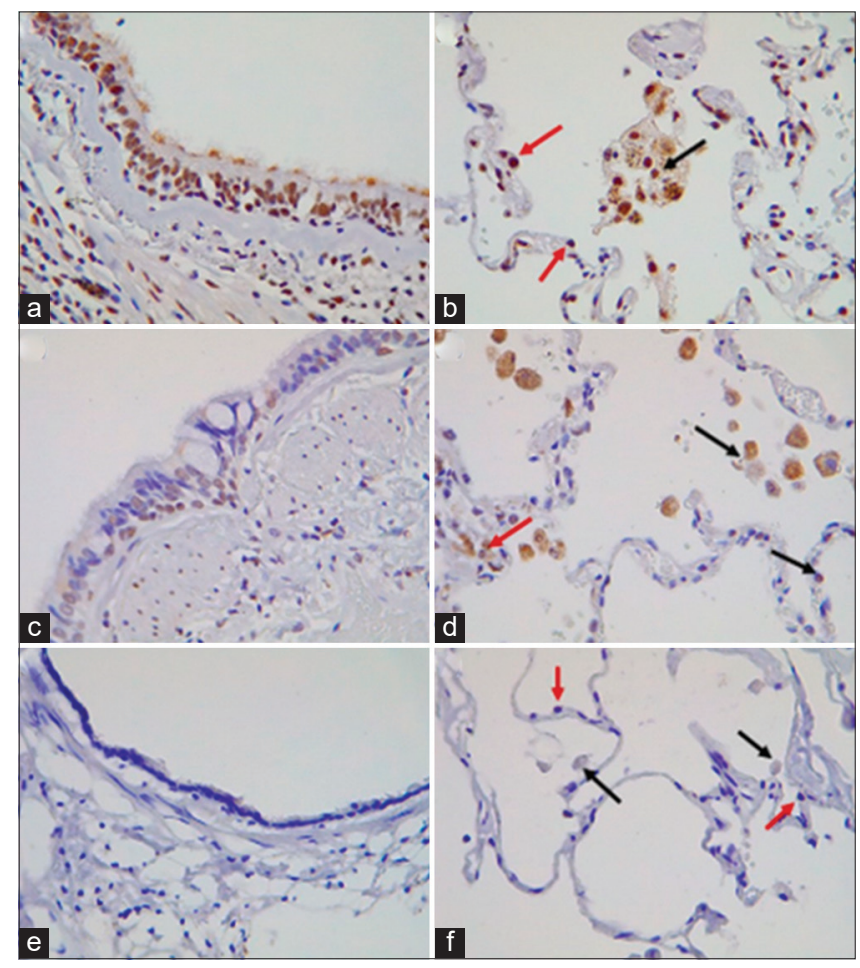

Figure 1: Smokers and chronic obstructive pulmonary disease (COPD) patients lung profile for the expression of angiotensin-converting enzyme-2 (ACE2) receptor [6]. Coloring on lung tissue resection for the receptor of ACE2. A COPD on current smokers (COPD-CS) with small airway epithelium positive staining (a), and (b) red arrows show type-2 pneumocytes positive staining. Meanwhile, the black one indicates alveolar macrophages positive of ACE2 receptor in airway apical including cilia. (c) and (d) represent normal lung function smoker with COPD-CS similar pattern and observed less staining. No staining was detected on normal controls in (e) and (f).

The viral processes and human immune response are essential biological processes related to genes associated with ACE2 [21]. CS induces the ACE2 expression patterns in the lower respiratory tract [20], and its elevation was revealed in intrapulmonary airways and oral epithelial cells among smokers [21]. ACE2 expression was observed to be significantly reduced after a long period of smoking inactivity; an outcome that even led some patients to quit their smoking habit [21]. This condition is identified to promote a further attention relating to people using waterpipe smoking [24], as well as those who switched to the electronic cigarettes and "heat-not-burn" IQOS devices [25]. Thus, both conventional and the most recent smoking devices present high risks of their users suffering from serious lung infection [25].

Another study described more detail regarding ACE2 gene expression in the airways among smokers; a level which is significantly higher compared to former smokers and non-smoking groups (smokers $=2.77 \pm 0.91$, former smokers $=2.00 \pm 1.23$, and non-smokers $=1.78 \pm 0.39$ ) [20]. This susceptibility to the bacterial and viral infection in the lung is higher among 
Table 2: The role of angiotensin-converting enzyme 2 on COVID-19 cases

\begin{tabular}{|c|c|c|c|c|c|}
\hline S. No. & Authors/Year & Title & Purposes & $\begin{array}{l}\text { Research Design, population, and } \\
\text { instrument }\end{array}$ & Result \\
\hline 1 & Zhang et al. (2020) & $\begin{array}{l}\text { Angiotensin-converting enzyme } \\
2 \text { as a severe acute respiratory } \\
\text { syndrome coronavirus } 2 \text { receptor: } \\
\text { molecular mechanisms and } \\
\text { potential therapeutic target. }\end{array}$ & $\begin{array}{l}\text { Review the rationale for } \\
\text { angiotensin-converting enzyme } 2 \\
\text { receptor as a specific target }\end{array}$ & $\begin{array}{l}\text { Research design: literature review } \\
\text { Sample: selected } 35 \text { articles } \\
\text { Instrument: biochemical interaction } \\
\text { studies and crystal structure analysis }\end{array}$ & $\begin{array}{l}\text { The human Angiotensin-converting } \\
\text { enzyme } 2 \text { is proven to have strong } \\
\text { binding affinity with severe acute } \\
\text { respiratory syndrome coronavirus } 2 \\
\text { spike protein }\end{array}$ \\
\hline 2 & Rabi et al. (2020) & $\begin{array}{l}\text { Sars-cov-2 and coronavirus } \\
\text { disease 2019: What we know so } \\
\text { far. Pathogens }\end{array}$ & $\begin{array}{l}\text { A summary of current knowledge } \\
\text { regarding the novel coronavirus and } \\
\text { the disease it causes }\end{array}$ & $\begin{array}{l}\text { Research design: Literature review } \\
\text { Sample: Studies of } 82 \text { articles } \\
\text { related to Covid-19 } \\
\text { Instrument:- }\end{array}$ & $\begin{array}{l}\text { The findings among smokers that } \\
\text { Angiotensin-converting enzyme } 2 \text { gene } \\
\text { expression was increasing significantly }\end{array}$ \\
\hline 3 & Brake et al. (2020) & $\begin{array}{l}\text { Smoking Upregulates } \\
\text { Angiotensin-Converting Enzyme-2 } \\
\text { Receptor: A potential adhesion site } \\
\text { for novel coronavirus severe acute } \\
\text { respiratory syndrome coronavirus } \\
2 \text { (COVID-19). }\end{array}$ & $\begin{array}{l}\text { Research and investigation of } \\
\text { Angiotensin-converting enzyme } \\
2 \text { that could be a novel adhesion } \\
\text { molecule for severe acute } \\
\text { respiratory syndrome coronavirus } \\
2 \text { which causing Covid- } 19 \text { and } \\
\text { a potential therapeutic target for } \\
\text { the prevention of fatal microbial } \\
\text { infections }\end{array}$ & $\begin{array}{l}\text { Research design: Literature review } \\
\text { Sample: Studies of } 40 \text { articles } \\
\text { related to COVID-19 } \\
\text { Instrument: surgical resected lungs } \\
\text { of smokers and chronic obstructive } \\
\text { pulmonary diseases patients }\end{array}$ & $\begin{array}{l}\text { The upregulation on } \\
\text { Angiotensin-converting enzyme } 2 \text { has } \\
\text { correlated with smoking status, leading } \\
\text { smokers and chronic obstructive } \\
\text { pulmonary disease patients are more } \\
\text { vulnerable to COVID-19. }\end{array}$ \\
\hline 4 & Sorour (2020) & $\begin{array}{l}\text { Angiotensin-converting enzyme } \\
2 \text { in the highlight of COVID-19, A } \\
\text { proposed pathology and potential } \\
\text { correlations }\end{array}$ & $\begin{array}{l}\text { Provide a summary of Clinical trials } \\
\text { that concluded the protective roles of } \\
\text { Angiotensin-converting enzyme } 2 \text { in } \\
\text { the lungs and brain }\end{array}$ & $\begin{array}{l}\text { Research design: Literature review } \\
\text { Sample: Clinical trials that } \\
\text { concluded the protective roles of } \\
\text { Angiotensin-converting enzyme } 2 \text { in } \\
\text { the lungs and brain } \\
\text { Instrument: }\end{array}$ & $\begin{array}{l}\text { Viral mediated of COVID-19 cases has } \\
\text { a correlation on Angiotensin-converting } \\
\text { enzyme } 2 \text { regulation. Further, there } \\
\text { is potential correlation between } \\
\text { COVID-19 disease severity and male } \\
\text { gender and smoking }\end{array}$ \\
\hline 5 & Leung et al. (2020) & $\begin{array}{l}\text { Angiotensin-converting enzyme } \\
2 \text { Expression in the Small } \\
\text { Airway Epithelia of Smokers and } \\
\text { chronic obstructive pulmonary } \\
\text { disease Patients: Implications for } \\
\text { COVID-19. }\end{array}$ & $\begin{array}{l}\text { Determined whether patients with } \\
\text { chronic obstructive pulmonary } \\
\text { disease have increased expression } \\
\text { of Angiotensin-converting enzyme } 2 \\
\text { in bronchial epithelial cells in lower } \\
\text { respiratory tract }\end{array}$ & $\begin{array}{l}\text { Research design: Mixed method } \\
\text { Sample: Patients undergoing } \\
\text { bronchoscopy at St. Paul's Hospital, } \\
\text { Vancouver, Canada, which were } \\
\text { required to be } 19 \text { years of age or } \\
\text { older } \\
\text { Instruments: Cytological brushing } \\
\text { using RNeasy Mini Kit (Qiagen, } \\
\text { Hilden, Germany); FastQC; } \\
\text { RSEM (RNA-Seq by Expectation } \\
\text { Maximisation); Limma voom; the } \\
\text { Cornell Dataset; British Columbia } \\
\text { Cancer Agency cohort; the Bond } \\
\text { Polymer Refine Red Detection } \\
\text { kit on a Leica Bond Autostainer; } \\
\text { Kruskal-Wallis with Dunn's Multiple } \\
\text { Comparisons tests }\end{array}$ & $\begin{array}{l}\text { Angiotensin-converting enzyme } \\
2 \text { expressed gene levels of the } \\
\text { participants airway was significantly } \\
\text { correlated with current smoking status. } \\
\text { This higher gene expression was } \\
\text { founded among smokers compared to } \\
\text { non-smokers samples. }\end{array}$ \\
\hline 6 & Wang et al. (2020) & $\begin{array}{l}\text { Susceptibility analysis of } \\
\text { COVID-19 in Smokers Based on } \\
\text { Angiotensin-converting enzyme } 2\end{array}$ & $\begin{array}{l}\text { Determine whether cigarette } \\
\text { smoking is a susceptibility factor for } \\
\text { COVID-19 }\end{array}$ & $\begin{array}{l}\text { Research design: Statistical analysis } \\
\text { Sample: The samples in GSE994 } \\
\text { were obtained from intrapulmonary } \\
\text { airways from normal smoking and } \\
\text { non-smoking volunteers (including } \\
34 \text { current smokers, } 23 \text { never } \\
\text { smokers, and } 18 \text { former smokers). } \\
\text { The overall design of GSE17913 } \\
\text { involved oral biopsy from } 40 \\
\text { current smokers and } 40 \text { age- and } \\
\text { gender-matched never smokers. } \\
\text { We also extracted } 55 \text { samples } \\
\text { from } 14 \text { different groups in the } \\
\text { GSE18344 dataset, including a } \\
\text { sham group (sham) and exposure } \\
\text { group. The mice in the exposure } \\
\text { group were continuously exposed } \\
\text { to cigarette smoke (750 } \mu \text { g total } \\
\text { particulate matter/L) for } 2,3 \text {, or } 4 \text { h/ } \\
\text { day (our low, medium, and high dose } \\
\text { groups, respectively) } \\
\text { Instrument: Three } \\
\text { datasets (GSE994, GSE17913, } \\
\text { and GSE18344), were downloaded } \\
\text { from the Gene Expression } \\
\text { Omnibus (GEO) database. }\end{array}$ & $\begin{array}{l}\text { Genes associated with } \\
\text { Angiotensin-converting enzyme } 2 \\
\text { were enriched in important biological } \\
\text { processes such as viral processes } \\
\text { and immune response. Elevated } \\
\text { Angiotensin-converting enzyme } \\
2 \text { was found in intrapulmonary } \\
\text { airways (GSE994) and oral epithelial } \\
\text { cells (GSE17913) of smokers but } \\
\text { not those of non-smokers or former } \\
\text { smokers. Significant dose- and } \\
\text { time-dependent relationships } \\
\text { between current smokers and } \\
\text { angiotensin-converting enzyme } 2 \\
\text { expression were observed in mouse } \\
\text { lung tissues, and long periods without } \\
\text { smoking were found to significantly } \\
\text { reduce angiotensin-converting enzyme } \\
2 \text { expression }\end{array}$ \\
\hline 7 & Zhou et al. (2020) & $\begin{array}{l}\text { A pneumonia outbreak associated } \\
\text { with a new coronavirus of probable } \\
\text { bat origin }\end{array}$ & $\begin{array}{l}\text { Report the identification and } \\
\text { characterization of a new } \\
\text { coronavirus ( } 2019-\mathrm{nCoV}) \text {, which } \\
\text { caused an epidemic of acute } \\
\text { respiratory syndrome in humans in } \\
\text { Wuhan, China }\end{array}$ & $\begin{array}{l}\text { Research design: qPCR-based } \\
\text { detection method } \\
\text { Sample: Seven patients with severe } \\
\text { pneumonia } \\
\text { Instrument: High Pure Viral RNA } \\
\text { kit (Roche); anti-SARSr-CoV IgG } \\
\text { and IgM ELISA kits; Lipofectamine } \\
\text { 3000; BGI MGISEQ2000 and } \\
\text { Illumina MiSeq } 3000 \text { sequencers; } \\
\text { DNAStar; MAFFT (v. 7.307); } \\
\text { PAL2NAL (v. 14); Clustal Omega (v. } \\
\text { 1.2.4); RAxML (v. 0.9.0) }\end{array}$ & $\begin{array}{l}\text { This study shows that } 2019-\mathrm{nCoV} \text { is } \\
96 \% \text { identical at the whole-genome } \\
\text { level to a bat coronavirus. Pairwise } \\
\text { protein sequence analysis of seven } \\
\text { conserved non-structural proteins } \\
\text { domains show that this virus belongs } \\
\text { to the species of SARSr-CoV. In } \\
\text { addition, } 2019-n C o V \text { virus isolated from } \\
\text { the bronchoalveolar lavage fluid of a } \\
\text { critically ill patient could be neutralized } \\
\text { by sera from several patients. Notably, } \\
\text { this study confirmed that } 2019-n C o V \\
\text { uses the same cell entry receptor- } \\
\text { angiotensin converting enzyme II-as } \\
\text { severe acute respiratory syndrome } \\
\text { coronavirus }\end{array}$ \\
\hline
\end{tabular}


smokers due to the damage caused by their smoking habit [6]. The SARS-CoV has the $80 \%$ homology with SARS-CoV-2 and is using the cell entry receptor, ACE2 [26]. A current research explored the possibility of two other receptors, namely, DC-SIGN and L-SIGN, finding that the DC-SIGN has higher gene expression among the lungs of former smokers [26].

\section{Conclusion}

As tobacco use is positively correlated with the presence of ACE2, a molecule for novel adhesion on SAR-CoV-2, and which can reduce human immunity towards new infection, it is essential to collect all data on the status of smoking and confirmed cases of COVID-19. The potential of coronavirus exacerbations and deceased cases need to be further investigated by taking into account tobacco use; including water pipes, ENDS, and "heat-not-burn" devices, IQOS. Furthermore, as this pandemic affects the global population, a comprehensive policy decision regulating the use, distribution, and advertisement, as well as the promotion and sponsorship activities of cigarette and other tobacco-related products should be prioritized, based on the WHO Framework Convention on Tobacco Control.

\section{Acknowledgments}

The study acknowledges all researchers and authors whose published articles were used in this review. The study involved no conflict of interests. No related donors were involved during this study's development. DS contributed to data collection, analysis of findings, and manuscript development. RL and SDH contributed to data analysis and manuscript reviews.

\section{References}

1. Romanov BK. Coronavirus disease COVID-2019. Saf Risk Pharmacother. 2020;8(1):3-8.

2. Zhang H, Penninger JM, Li Y, Zhong N, Slutsky AS. Angiotensinconverting enzyme 2 (ACE2) as a SARS-CoV-2 receptor: Molecular mechanisms and potential therapeutic target. Intensive Care Med. 2020;46(4):586-90. https://doi.org/10.1007/ s00134-020-05985-9

PMid:32125455

3. Chen T, Wu D, Chen H, Yan W, Yang D, Chen G, et al. Clinical characteristics of 113 deceased patients with Coronavirus disease 2019: Retrospective study. BMJ. 2020;368:m1091. https://doi.org/10.1136/bmj.m1091

PMid:32217556

4. Rabi FA, Al Zoubi MS, Kasasbeh GA, Salameh DM Al-Nasser AD. SARS-CoV-2 and Coronavirus disease 2019: What we know so far. Pathogens. 2020;9(3):231. https://doi. org/10.3390/pathogens 9030231 PMid:32245083

5. Sarma P, Prajapat M, Avti P, Kaur H, Kumar S, Medhi B. Therapeutic options for the treatment of 2019-novel Coronavirus: An evidence-based approach. Indian J Pharmacol. 2020;52(1):1-5.https://doi.org/10.4103/ijp.ijp_119_20 PMid:32201439

6. Brake SJ, Barnsley K, Lu W, McAlinden KD, Eapen MS, Sohal SS Smoking upregulates angiotensin-converting enzyme-2 receptor: A potential adhesion site for novel Coronavirus SARSCoV-2 (COVID-19). J Clin Med. 2020;9(3):841. https://doi. org/10.3390/jcm9030841

PMid:32244852

7. Murukutla N. Communication Strategies for Smokeless Tobacco Control and Prevention. Available from: https://www. untobaccocontrol.org/kh/smokeless-tobacco/wp-content/ uploads/sites/6/2017/12/dr.nandita.pdf. [Last accessed on 2021 Mar 03].

8. World Health Organization. Regional Action Plan for the Tobacco Free Initiative in the Western Pacific (2015-2019). Available from: https://www.apps.who.int/iris/handle/10665/208180.[Last accessed on 2021 Mar 03].

9. Murukutla N, Strategies V, Turk T. Using Strategic Health Communication for Tobacco Control in India. Available from: https://www.vitalstrategies.org/resources/using-healthcommunication-effectively-for-smokeless-tobacco-control-inind. [Last accessed on $2021 \mathrm{Mar}$ 03].

10. Byron MJ, Cohen JE, Frattaroli S, Gittelsohn J, Drope JM, Jernigan $\mathrm{DH}$. Implementing smoke-free policies in low-and middle-income countries: A brief review and research agenda. Tob Induc Dis. 2019;17:60. https://doi.org/10.18332/tid/110007 PMid:31582949

11. Khan KS, Kunz R, Kleijnen J, Antes G. Five steps to conducting a systematic review. J R Soc Med. 2003;96(3):118-21. https:// doi.org/10.1258/jrsm.96.3.118

PMid:12612111

12. Sandelowski M, Barroso J, Voils Cl. Using qualitative metasummary to synthesize qualitative and quantitative descriptive findings. Res Nurs Health. 2007;30(1):99-111. https://doi.org/10.1002/nur.20176

PMid:17243111

13. Rother ET. Systematic literature review $X$ narrative review ACTA Paul Enferm. 2007;20(2):7-8.

14. World Health Organization. Tobacco and Waterpipe use Increase the Risk of Suffering from COVID-19. Geneva: World Health Organization; 2020. p. 10.

15. Sorour K. ACE-2 in the Highlight of COVID-19, a Proposed Pathology and Potential Correlations, Central Open Science; 2020.

16. Vardavas C, Nikitara K. COVID-19 and smoking: A systematic review of the evidence. Tob Induc Dis. 2020;18:20. https://doi. org/10.18332/tid/119324 PMid:32206052

17. Lewis T. Smoking or Vaping May Increase the Risk of a Severe Coronavirus Infection, Scientific American; 2020. p. 1-8. Available from: https://www.scientificamerican.com/ article/smoking-or-vaping-may-increase-the-risk-of-a-severecoronavirus-infection1. [Last accessed on 2020 May 25].

18. Starace F, Ferrara M. COVID-19 disease emergency operational instructions for mental health departments issued by the Italian 
society of epidemiological psychiatry. Epidemiol Psychiatr Sci. 2020;29:e116. https://doi.org/10.1017/s2045796020000372

PMid:32228737

19. Jordan RE, Adab P, Cheng KK. COVID-19: Risk factors for severe disease and death. BMJ. 2020;368:m1198. https://doi. org/10.1136/bmj.m1198

PMid:32217618

20. Leung JM, Yang CX, Tam A, Shaipanich T, Hackett TL, Singhera GK, etal.ACE-2Expression in the SmallAirway Epithelia of Smokers and COPD Patients: Implications for COVID-19, medRxiv; 2020. https://doi.org/10.1183/13993003.00688-2020

21. Wang J, Luo Q, Chen R, Chen T, Li J. Susceptibility Analysis of COVID-19 in Smokers Based on ACE2; 2020. p. 1-8.

22. Zhou P, Lou YX, Wang XG, Hu B, Zhang L, Zhang W, et al. A pneumonia outbreak associated with a new Coronavirus of probable bat origin. Nature. 2020;579(7798):270-3 PMid:32015507

23. Simons D, Perski O, Brown J. COVID-19: The role of smoking cessation during respiratory virus epidemics. BMJ. 2020;2020:20-2.

24. Meo SA, AlShehri KA, AlHarbi BB, Barayyan OR, Bawazir AS, Alanazi OA, et al. Effect of shisha (waterpipe) smoking on lung functions and fractional exhaled nitric oxide (FeNO) among Saudi young adult shisha smokers. Int J Environ Res Public Health. 2014;11(9):9638-48. https://doi.org/10.3390/ ijerph110909638

PMid:25233010

25. Sohal SS, Eapen MS, Naidu VG, Sharma P. IQOS exposure impairs human airway cell homeostasis: Direct comparison with traditional cigarette and E-cigarette. ERJ Open Res. 2019;5(1):00159-2018. https://doi. org/10.1183/23120541.00159-2018

PMid:30775377

26. Cai G, Cui X, Zhu X, Zhou J. A Hint on the COVID-19 Risk: Population Disparities in Gene Expression of Three Receptors of SARS-CoV; 2020. https://doi.org/10.20944/ preprints202002.0408.v1 